\title{
COMMUNITY GUIDANCE ASSIGNMENT PANDEMIC OVID-19 AND NEW NORMAL PREPARATION IN CLASS I CORRECTIONAL HALL OF BANDUNG
}

\author{
Vivi Sylviani Biafri ${ }^{a^{*}}$ \\ ${ }^{a)}$ Politeknik Ilmu Pemasyarakatan, Depok, Indonesia \\ ${ }^{*}$ Corresponding Author: vivi_biafri@yahoo.com
}

Article history: received 09 August 2020; revised 28 August 2020; accepted 30 August 2020

\begin{abstract}
The spread of corona virus in Indonesia is known to occur in March 2020 with positive corona cases found in Depok, West Java. Within 3 months, most cities in Indonesia contained corona patients. In July 2020, the Indonesian people will start a new life. This new life order will be applied to all walks of life. Changes will occur for civil servants or private employees in carrying out daily tasks. One of the experienced changes is Community Guidance. Community Guidance is a civil servant within the Directorate General of Corrections of the Ministry of Justice and Human Rights. These Community Guides have direct contact with their clients. Therefore, we need innovations to do the work. The research question is How does the Community Guidance do their work during the co-19 pandemic and new normal preparations at Class I Correctional Hall of Bandung? What impact will it have on Community Guidance at Class I Correctional Hall of Bandung? The purpose of this research is to analyze how the Community Guidance in carrying out tasks in the co-19 pandemic and the preparation of new normal and their impact on them. This study uses a qualitative method. The approach used is a descriptive approach. The research location is Class I Correctional Hall of Bandung. The results showed that the community guidance in carrying out their tasks during the co-19 pandemic used a lot of information technology. Therefore, community guidances are required to be able to operate the applications used.
\end{abstract}

Keywords: task; community guidance; correctional hall

\section{INTRODUCTION}

The new normal will begin to be implemented in several areas that are proven to be safe at Covid-19. At least 102 regions have been allowed by the government through the Covid-19 Handling Acceleration Task Force to implement new normal. Not without reason, the government has begun implementing new normal in some of these areas. Vice President Ma'ruf Amin said, new normal would not have to be carried out in order to avoid the danger of Covid19 transmission as well as the economic downturn [1]. With this government decision, all sectors must prepare themselves to enter life in the new normal era. Each sector must make adjustments to this new life. Private and government offices must also prepare a new life order in the office environment.

For civil servants, new work procedures in the work environment are regulated and established through the Ministry of Administrative Reform and Bureaucratic Reform of the Republic of Indonesia. In a Circular Letter Minister of Administrative Reform and Bureaucratic Reform No. 58/2020 concerning the Work System of Civil Servants in the New Normal Order are emphasized that civil servant continues to carry out its duties and functions productively. In Jakarta itself with the large-scale social restrictions transition period, government offices can implement work in offices with a maximum of 50\% attendance of employees in one office. Every state civil servant who works in an office must use a mask in undergoing a new system. The state civil apparatus is also required to adjust the distance of seats as far as 1.5 to 2 meters, maintain distance or social / physical distancing during meetings, and reduce work visits by conducting meetings via online [2]. In more detail the Circular Letter of the Minister of Administrative Reform and Bureaucratic Reform No. 58/2020 concerning the Work System of Civil Servants in the New Normal Order are regulated by each ministry / institution. This is done because the task sectors of each ministry / institution are different.

The Ministry of Law and Human Rights is one of the ministries that has 11 echelon I units. Each echelon I unit has a different function. One of the echelon I units that has the most technical units is the Directorate General of Corrections. The Directorate General of Corrections has 525 correctional units in prison/detention centers and 90 correctional hall spread throughout Indonesia. Community Guidance is a specific functional position in the ranks of the Directorate General of Corrections. Community Guidance can be assigned to the Head Office (Directorate General of Corrections), the Office of the Ministry of Law and Human Rights at the provincial level and the Class I or class II Correctional Hall.

During the ovid-19 pandemic, the Community Guidance continued to work by referring to the Circular Letter of the Minister of Administrative Reform and Bureaucratic Reform No. 58/2020 concerning the Work System of Civil Servants in the New Normal Order. Duties carried out by the Community Guidance include preparing 
social research reports, assisting children in dealing with the law, advising, supervising and attending the Correctional Observer Team sessions. The task of community guidance at the Class I Correctional Hall of Bandung is quite heavy because they serve quite large clients. The number of community guidance and community guidance assistant is 61. The number of clients in the Class I Correctional Hall of Bandung is 4,979 people consisting of 4,870 adult clients and 109 child clients (Source: Class I Correctional Hall of Bandung as of 30 June 2020). So, one community guidance has approximately 82 clients. In addition, the task area of the Class I Correctional Hall of Bandung is quite extensive covering seven cities / districts, namely Bandung City, Bandung districts, West Bandung districts, Cimahi City, Cianjur districts, Sukabumi districts and Sukabumi City. The remotest areas are Sukabumi districts and Sukabumi City.

The main tasks and functions in general are things that must even be done by an organization member or employee in an agency regularly in accordance with its ability to complete work programs that have been made based on the goals, vision and mission of the organization [3]. The current vision and mission are the vision and mission of the President of the Republic of Indonesia. The President's vision and mission are elaborated in the function of ministries / institutions. The vision and mission of President R.I are:

a. Infrastructure development will continue;

b. Human-resource development;

c. Investment must be invited as widely as possible;

d. Bureaucratic reform;

e. Guarantee the use of a focused and targeted State Expenditure Budget.

In the translation of the vision and mission of the Correctional Staff has a strategic stake. Guidance of inmates and children so that they can return and be accepted in the midst of the community is part of human-resource development. The noble task is carried out by the Community Guidance. As a government institution, correctional hall have duties and functions including :

a. Providing Providing social guidance and alleviation of children in accordance with applicable laws and

b. Carry out coaching, assistance, guidance and supervision of clients outside the prison.

The function of the correctional center include:

a. Conducting community research as material for consideration in the Community Correctional Development program based on requests from prisons, detention centers or other correctional hall.

b. Registering correctional clients.

c. Conduct community guidance and alleviation of children.

d. Attends hearings in district courts and Correctional Observation Teams in Correctinal Hall, Prison or Detention Center.

e. Carrying out mental, social guidance and work training, whether conducted alone or in other institutions; and

f. Carry out corectinal hall administrative matters

The spearhead of the implementation of the function of the correctinal hall function is the community guidance.
In carrying out the duties of a community guidance must have competence. Competence is defined as the ability needed to do or carry out work based on knowledge, skills and work attitudes. A person's ability or competence is high or low can be proven when he is doing work. It means competence not only knows what needs to be done but does what is known. The habit of thinking and acting consistently and continuously will make someone competent. In detail, there are five dimensions of competency that must be possessed by individuals, namely [3]:

1. Task skills are skills to carry out routine tasks in accordance with standards at work.

2. Task management skills, namely skills to manage a series of different tasks that arise in the job.

3. Contingency management skills, namely skills to take quick and appropriate action if a problem arises in a job.

4. Job role environment skills, namely skills to work together and maintain the work environment and

5. Transfer skills, namely skills to adapt to the new work environment.

This competency can be formed through continuous technical education and training.

To help the task of correctional guidance to make it easier and more efficient, the use of information technology has a big contribution. According to Wahyudi [4], information technology can be interpreted as electronic technology that can able to support the acceleration and improve the quality of information, as well as the acceleration of information flow so that it is no longer limited by space and time. Meanwhile according to Sulistiyo-Basuki [4], information technology, is the technology used to store, produce, process, and disseminate information. This information includes four categories, namely (a) numeric, usually in the form of numbers; (b) audio, usually in the form of sound; (c) text, usually in the form of writing; and (d) imagery, usually in the form of images and graphics. Furthermore, according to him, technology is not only limited to hardware (tools) and software (programs) but also includes humans and the objectives determined, the value used to decide whether humans control technology and are enriched by technology or not.

Research related to the task of Correctional Guidance in the 19th pandemic, and the new normal era has never been done. Therefore, this study aims to analyze the ways taken by the Correctional Guidance in carrying out tasks in the ovid-19 pandemic period and the preparation of new normal and their impact on the correctional guidance. The focus of this research is (1). How does the Correctional Guidance carry out their duties during the co-19 pandemic and new normal preparations at Class I Correctional Hall of Bandung? (2) What is the impact of the use of information technology for Correctional Guides in carrying out their duties at the Class I Correctional Hall of Bandung?

\section{RESEARCH METHODS}

The research method used is qualitative. According to Creswell, qualitative research is methods to explore and 
understand the meaning that by a number of individuals or groups of people ascribed social or humanitarian problems [5]. According to Bogdan and Taylor qualitative methodology as a research procedure that produces descriptive data in the form of written or oral words from people and observable behavior. According to Bogdan and Taylor, this approach is directed to the setting and individual holistically (intact) [6]. Denzin and Lincoln stated that qualitative research was research uses a natural setting, with the intention of interpreting phenomena occur and is carried out by involving various existing methods [6].

The characteristic of this research is descriptive research which is intended to describe a phenomenon by examining it regularly, prioritizing objectivity, and being done carefully [7]. There are two data sources used in this study, namely primary and secondary data sources. Primary data sources were obtained by conducting interviews with correctional guidances and the Head of Class I Correctional Hall of Bandung as research subjects and observing in the field. Secondary data sources were obtained by studying all statutory regulations, journals and news.

Data analysis techniques used in this research are based on the opinion of Miles and Huberman, namely: data reduction, data presentation, and drawing conclusions (verification) [8]. These three data analysis processes are simultaneous and interactive cycles. For more details can be seen in the following picture:

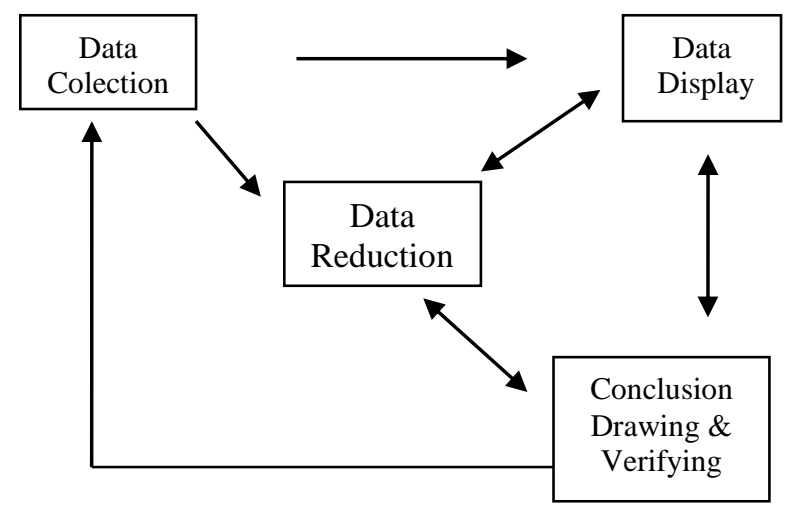

Figure 1. Analysis processes are simultaneous and interactive cycles

\section{RESULTS AND DISCUSSION}

1. Implementation of Correctional guidances task Before Covid-19 Pandemic

Before the corona virus pandemic occurred, the Community Guidance in carrying out the task of making social research, assisting children in conflict with the law, guiding, supervising and attending the Correctional Observer Team sessions was carried out in a conventional manner. What is meant by conventional means are ways that do not utilize information technology in these tasks. Community counselors to conduct community research must come to meet inmates and children. Conduct direct interviews (face to face) with inmates and children. Community Supervisor visits the guarantor house (family) of prisoners and children. In addition, the Community Supervisor visited the house of the Head of the Neighborhood Association and the Head of the Community Unit to obtain a statement stating that the community accepted the presence of prisoners and children who would undergo parole and assimilation. By working this way it is inefficient time and energy, besides the risk if something happens on the way. The length of time for making special research for children must be completed within $3 \times 24$ hours in accordance with the mandate of the Criminal-Justice System for Children.

Community research is divided into 2 namely community research for adult clients and community research for child clients. For a social studies children, clients are divided into community research for diversion, community research for trials, community research for handling children who are not yet 12 years old, community research for initial coaching, community research for integration programs, community research for mentoring and transfer [9]. Community Research for adult clients includes community research social reintegration, transfer and mentoring programs. In general, social research contains the identity of the client, the identity of the client's wife / wife / guarantor, a description of the crime that was alleged to the client, the life history and development of the client, the client's family condition, the client's neighborhood, the client's response and various parties to the client's problem problem, against the problem, the results of the assessment, analysis of client problems and conclusions and recommendations [9]. The purpose of social research is to determine the background of a person committing a crime both originating from within himself or from outside himself. While social research for children aims to be a material consideration for helping judges to make an appropriate and fair decision and to determine coaching therapy [10].

For the assistance of children in a court hearing, the Community Guidance must attend the hearing in the court that has been determined. The children's trial is conducted in private. The hearing was attended by judges, children, children's families, correctional guidances, child lawyers, victims 'families and victims' children (if there were victims). The trial is conducted conventionally, all present in the courtroom together.

The task of guiding and supervising the client is carried out by way of the correctional guidances visiting the client's home or the client comes to the Class I Correctional Hall of Bandung in accordance with the specified schedule. From the client side must spend special time, if the client is already working, then this will interfere with his work. In addition it will burden the client for transportation costs if the distance of the client's house to Class I Correctional Hall of Bandung is far. Most of the clients in the Class I Correctional Hall of Bandung has poor economic status.

From the side of the correctional guidances, it is quite troublesome if I have to always visit the client's house to conduct guidance and supervision. The transportation budget 
for all correctional guidances tasks in Class I Correctional Hall of Bandung is very limited and often inadequate. Also the risk of exposure to the virus is greater.

Following the preliminary observer team hearing at the correctional hall is one of the tasks of the correctional guidances. In this trial, all prisoners' and children's social studies are discussed at the hearing. The trial determining prisoners and child was approved for proposed parole and assimilation. Correctional guidances must be present to provide an explanation to members of the court regarding their clients who are proposed parole. The trial is conducted conventionally in a closed room specifically used for meetings. The small space is only able to accommodate 25 people while the number of correctional guidances in Class I Corretional Hall of Bandung are 61 people.

2. Implementation of Correctional Guidances Assignments In The Covid-19 Pandemic And New Normal Preparation

When the co-19 pandemic occurred in Indonesia, the Indonesian government-imposed large-scale social restrictions. During this period, there were significant changes in almost all sectors. In the government ranks, including civil servants, the rules of working from home are enacted. In the correctional unit imposed a picket system. This is done to limit the gathering of large numbers of employees in a room. Services to the community are still being carried out. Likewise, what happened with the correctional guidances. The picket system is in effect until the end of June and the beginning of July all work as usual. This decision was taken by the Head of Class I Correctional Hall of Bandung because the services that must be provided to clients must continue.

Correctional Guidance in carrying out the task of making social research, mentoring children who are in conflict with the law, guiding, supervising and carrying out hearings of the Correctional Observation Team conducted by utilizing information technology. In making a social report correctional guidances does not visit the families of prisoners and children to the guarantor's house. Interviews were conducted virtually using a video call application with inmates and children and their families as guarantors. A visit to the house of the Head of the Neighborhood Association and the Head of the Community Unit to obtain a statement stating that the community accepts the presence of prisoners and children who will undergo parole and assimilation is also carried out via a video call. How to work like this is more efficient time, energy, cost, the risk of accidents in travel is lower and the risk of exposure to the corona virus is smaller. Making special research for children can still be completed within $3 \times 24$ hours in accordance with the mandate of the Criminal- Justice System for Children.

For the assistance of children in court, it is conducted virtually by the Correctional Guidance in accordance with the schedule that has been determined. The hearing was attended by judges, children, children's families, correctional guidances, child lawyers, victims 'families and victims' children (if there were victims). The trial is held virtually using the zoom application. According to one correctional guidances, this is more effective because even in the conditions of the trip the correctional guidances can attend the children's hearing.

The task of guiding and supervising clients is carried out in a virtual way. Correctional guidances provide guidance and supervision using video calls. In this way, the correctional guidances can actually communicate longer with the client's family. In addition, the involvement of the Head of the Neighborhood Unit and the Head of the Community Unit where the client lives in supervising the client is higher. This method is cheaper and effective.

Attending a correctional observer team session at the correctional hall is one of the tasks of the correctional guidances. The trial discussed and determined that prisoners and children were approved or rejected for conditional release and assimilation. The correctional guidance is obliged to attend the hearing to provide an explanation to the members of the court regarding their proposed client's parole and assimilation. The trial in the Ovid-19 and new normal pandemic period was conducted virtually using the zoom application. The online system trial is safer and is attended by all correctional guidances. Duties of Community Guidance carried out online during the epidemic ovid-19 in accordance with the Guidelines for implementing social research and online mentoring as well as guiding and supervising client assimilation and integration in the framework of preventing \& controlling the spread of Ovid19 signed on April 13, 2020 by Officials while Director General of Corrections.

In addition to using the zoom and video call application, the correctional guidances at Class I Correctional Hall of Bandung also uses Google forms to request an assessment of the services they provide to clients. This is a replacement for the suggestion box. For administration and correspondence also uses the application. The files of prisoners and children who obtained parole and assimilation from the prison/detention center were sent via Google's form to Class I Correctional Hall of Bandung. All correctional guidances can open the email.

The use of information technology in correctional guidances assignments has a positive impact. Correctional guidances are required to learn how to use new applications. Senior correctional guidances study with junior correctional guidances that are much younger but understand and master information technology more.

Judging from the explanation above, it can be seen that the correctional guidances in carrying out their duties during the epidemic of the 19th and new normal pandemics are more efficient in terms of energy, time, cost, safety risks in travel and higher risk of exposure. All correctional guidances tasks are carried out online by utilizing information technology. Administrative and correspondence reports are all carried out online. Utilization of information technology has a major impact on the implementation of correctional guidances tasks. Faster service process. Distance factor is no longer a reason to complete a task. This major change can occur due to advances in science and technology. According to Christine E. Sleeter \& Peter L said 
that there are three dominant forces namely: 1). Science, 2) Technology as the application of knowledge, 3) Information [11]. These three things are proven to bring great changes to the correctional guidances in carrying out their duties as public servants.

\section{CONCLUSION}

The use of information technology greatly helps the task of correctional guidances so that it is faster, more efficient, energy efficient, low risk of accidents on the trip, saves money and reduces the risk of corona virus exposure. In addition, cooperation between the police, the Chairman of the Neighborhood Association, the Chairman of the Community Unit and the Correctional guidances is better than before. Supervision of the client during the Ovid-19 pandemic was carried out by involving the management of.

The weakness of the use of information technology is the limited ability of correctional guidances to operate or use new applications. Especially this happens with the old correctional guidances. In addition, internet signals that are sometimes not strong can be distracting. This is because the internet network at the Class I Correctional Hall of Bandung is not provided by the Directorate General of Corrections. So use a different provider from the Directorate General of Corrections. Lack of attention from the Directorate General of Corrections, especially the Directorate for Community Guidance and Eradication, to create standard questions in the Google form regarding client guidance and supervision. As a result, each correctional hall format has a different. There is even a correctional hall who does not use. The Directorate General of Corrections, especially the Directorate for Community Guidance and Eradication, submits the use of Google's forms in serving clients the decision is submitted to the Head of correctional hall.

\section{REFERENCES}

[1] https://nasional.kompas.com/read/2020/06/09/093124 61/new-normal-keberhasilannya-bergantung-pada-ke disiplinan-masyarakat?page $=3$

[2] https://finance.detik.com/berita-ekonomi-bisnis/d-504 9030/semua-pns-sudah-terapkan-new-normal-masihbisa-kerja-dari-rumah

[3] Rahmawati, Triani (2017). Kajian Pengaruh Tugas Pokok dan Fungsi Terhadap Kinerja Pustakawan Dalam Mengumpulkan Angka Kredit di Perpustakaan Nasional RI. Perpustakaan Nasional RI, Jakarta, p. 712

[4] Fatimah Zuhrah. Pentingnya Teknologi Informasi Dalam Meningkatkan Pelayanan di Perpustakaan. Jurnal Iqra' Volume 05 No.01 Mei, 2011, p. 41

[5] Creswell, John W. Research Design : Pendekatan Metode Kualitatif, Kuantitatif dan Campuran. Yogyakarta : Pustaka Pelajar, 2016, pp. 5.

[6] Moleong, Lexy J. Metodologi Penelitian Kualitatif. Bandung : PT. Remaja Rosdakarya, 2014, pp. 4-5
[7] Kusmiyanti. The Fostering of Corruption Inmates in Sukamiskin Class I Correctional Facility. Asia Pasific Fraud Journal Volume 3, No.2nd Edition (JulyDecember 2018), p. 279.

[8] Kusmiyanti and Vivi Sylviani : "Impact of OverCrowding In Correctional Institution On Health of Prisoner". Proceeding The International Conference On Social Work (ICSW), 2019: 3-4.

[9] Direktorat Jenderal Pemasyarakatan. Standar Penelitian Kemasyarakatan Anak. Jakarta : Ditjen Pemasyarakatan. 2015.

[10] Yohanes Pande. Jurnal Lex Librum, Vol. V, No. 1, Desember 2018, p.857

[11] Haris Budiman. Peran Teknologi Informasi dan Komunikasi Dalam Pendidikan. Al-Tadzkiyyah: Jurnal Pendidikan Islam, Volume 8 No. I, 2017, p. 36 